\title{
Improving growth and yield of potato through potassium and zinc fertilization
}

\author{
Mohammad Wasiullah Khan ${ }^{1 *}$, Abdur Rab ${ }^{1}$, Roshan Ali ${ }^{2}$, Muhammad \\ Sajid ${ }^{1}$, Muhammad Naeem Khan ${ }^{1}$, Akhtar Ali ${ }^{3}$, Muhammad Arif \\ Khan ${ }^{1}$, Waqas Pervez ${ }^{1}$ and Fazle Amin ${ }^{1}$ \\ 1. Department of Horticulture, The University of Agriculture, Peshawar, KPK-Pakistan \\ 2. Agricultural Research Institute (North) Mingora Swat, KPK-Pakistan \\ 3. Department of Agronomy, The University of Agriculture, Peshawar, KPK-Pakistan \\ *Corresponding author's email: wasikhan361@aup.edu.pk \\ Citation \\ Mohammad Wasiullah Khan, Abdur Rab, Roshan Ali, Muhammad Sajid, Muhammad Naeem Khan, Akhtar Ali, \\ Muhammad Arif Khan, Waqas Pervez and Fazle Amin. Improving growth and yield of potato through \\ potassium and zinc fertilization. Pure and Applied Biology. Vol. 7, Issue 3, pp992-997. \\ http://dx.doi.org/10.19045/bspab.2018.700117
}

\begin{tabular}{llll}
\hline \hline Received: 26/04/2018 & Revised: 05/07/2018 & Accepted: 09/07/2018 & Online First: 13/07/2018 \\
\hline
\end{tabular}

\section{Abstract}

A trial was carried out to evaluate the impact of potassium and Zinc on the growth and production of potato at Agricultural Research Institute Mingora Swat, during winter 2014. The trial was carried out in RCBD with two factors, and 3 replications. Four levels of potassium ( 0 , 90,120 and $\left.150 \mathrm{~kg} \mathrm{ha}^{-1}\right)$ and three zinc levels $\left(0,5\right.$ and $\left.10 \mathrm{~kg} \mathrm{ha}^{-1}\right)$ were used in the experiment. The various parameters studied during experiment were tillers number plant ${ }^{-1}$, leaves plant ${ }^{-1}$, plant height, number of tubers plant ${ }^{-1}$, and weight of tubers plant ${ }^{-1}$. Potassium and zinc application at various levels were significant for all parameters except emergence percentage. $120 \mathrm{~kg} \mathrm{~K} \mathrm{ha}^{-1}$ increased number of tillers plant ${ }^{-1}$ (3.0), leaves plant ${ }^{-1}$ (15.7), plant height (28.0 $\mathrm{cm})$, tubers plant ${ }^{-1}(11.9)$, weight of tubers plant $^{-1}(524 \mathrm{~g})$. Application at $10 \mathrm{~kg} \mathrm{Zn} \mathrm{ha-1}$ maximizes number of tillers plant ${ }^{-1}(2.9)$, number of leaves plant ${ }^{-1}(15.5)$, plant height (27.6 $\mathrm{cm})$, number of tubers plant ${ }^{-1}(11.3)$, tubers weight plant $^{-1}(503 \mathrm{~g})$. Most of the parameters were not significantly different from that of $5 \mathrm{~kg} \mathrm{Zn} \mathrm{ha}^{-1}$. None of the studied parameters was significantly affected by $\mathrm{K}$ and $\mathrm{Zn}$ interaction. On the basis of the current research, potassium $120 \mathrm{~kg} \mathrm{ha}^{-1}$ and zinc $5 \mathrm{~kg} \mathrm{ha}^{-1}$ gave maximum yield of potato in Swat valley.

Keywords: Potato; Potassium; Zinc

\section{Introduction}

Potato was originated from Bolivia and Peru. It belongs to family Solanaceae and its botanical name is (Solanum tuberosum L). In terms of production across the world potato is the fourth most main crop which occupies sixth place all over the world with the average being 15.3 ton $\mathrm{ha}^{-1}$ [1]. After sugar beet and sugarcane, potato is the third uppermost yielding crop due to fresh matter.

In Pakistan from 2010 to 2011 on an area of 15.94 thousand hectare potato was grown with the average yield of 18.5 ton $\mathrm{ha}^{-1}$. In Khyber Pakhtunkhwa during the same season, potato cultivated area was 8900 hectare with average yield of 13.4 tons per hectare [2].

Potato is an exhaustive crop with high yield and short duration. Therefore it is very important to apply fair fertilizers for quantitative and qualitative production from this imperative crop. All necessary nourishing substances must be present with enough quantity to maintain the maximum production with quality tuber and to restore 
soil fertility to attain advantageous development and growth of potato [3].

One of the most important factor in improving the quantity and quality of plants product is proper plant nutrition [4]. Potassium is one of the important plat nutrient that controls the translocation of the nutrients throughout the plant which effect both the general plant penology and also affects its quality and yield. It regulates nutrient solution which sustain the turgidity and thus control the movement and translocation of all components inside the plant body. Potassium plays an essential part during photosynthesis that facilitate the maximum energy level, maintaining stomatal conductance (opening and closing) on leaf, absorption of water, nutrients translocation, organic acid and vitamin contents in plants [5].

High doses of Nitrogen may lockup zinc as zinc protein complex in the root and these complexes may not be translocated to above plant [6]. The higher availability of phosphorous may prevent the translocation of zinc and render its metabolically inactive. The interaction of $\mathrm{Cu}^{+2}, \mathrm{Fe}^{+2}$, $\mathrm{Mn}^{+2}, \mathrm{Mg}^{+2}$, with zinc which may inhibits its uptake by plants [7].

Zinc is one of them that has a vital metabolic role in growth of plants and their development; therefore it is called as an essential micronutrient or trace element. In plants zinc is in the form of $\mathrm{Zn}^{2+}$ and is a crucial nutrient that has particular physiological purpose. Which act in all living systems, such as facilitation of protein creation, the maintenance of functional and structural integrity of biological membranes, gene expression, and production of energy, Krebs cycle and enzymes structure. Also has a positive effect on crops production. So crops qualitative and quantitative production strongly depends on Zinc in the soil [4]. To allow a number of key plant physiological passageways to function normally $\mathrm{Zn}$ is needed in minute but critical concentrations [8]. For crop yield and most favorable size of fruit, Zinc is a necessary element, also $\mathrm{Zn}$ is needed in the carbonic enzyme which are present in every photosynthetic tissue and which is required for chlorophyll biosynthesis [9].

In the present study this particular research work has been designed to examine the combined impact of $\mathrm{K}$ and Zinc on growth, quality, yield and production of potato crop.

\section{Materials and methods}

Field trial was carried out to examined the effects of potassium $(\mathrm{K})$ and zinc $(\mathrm{Zn})$ application on growth, yield and quality of potato at the Agricultural Research Institute (North) Mingora Swat, during winter 2014. Experiment was conducted in RCBD in factorial arrangement with 3 replications. There were Four levels of potassium $\left(0,90,120\right.$ and $\left.150 \mathrm{~kg} \mathrm{ha}^{-1}\right)$ and three zinc levels $\left(0,5\right.$ and $\left.10 \mathrm{~kg} \mathrm{ha}^{-1}\right)$ in the experiment. The plot size was $16 \mathrm{~m}^{2}$. The row to row and plant to plant distances were 75 and $25 \mathrm{~cm}$ respectively. The potato (Variety Allauddin) was sown on $12^{\text {th }}$ January, 2014. Potato cuts with diameter of $30 \mathrm{~mm}$ were sown. Nitrogen and phosphorous were given at the rate of 150 and $100 \mathrm{~kg} \mathrm{ha}{ }^{1}$. Three split doses of Nitrogen were used. All other standard practices were kept uniform for all treatments.

\section{Soil analysis}

Soil physical analysis indicated that soil class is silt-loam. While chemical analysis showed that $\mathrm{pH}$ of soil is acidic (6.4) in nature. Organic matter was moderate $(1.2 \%)$, lime $(2.6 \%)$ content showed slightly calcareous in nature, Nitrogen was at low rate $(0.03 \%)$, and phosphorus (30.6 ppm) showed medium range while potassium $(70.0 \mathrm{ppm})$ was reordered. The Soil analysis shows that $\mathrm{Zn}$ is not deficient i.e. $7.06 \mathrm{mg} \mathrm{kg}^{-1}$ but the plant analysis shows $\mathrm{Zn}$ deficiency i.e. $<20 \mathrm{ppm}$ this may be due to the following reason.

$\mathrm{Zn}$ application with high Nitrogen from $\mathrm{Zn}$ protein complex in the root which causes translocation problem of $\mathrm{Zn}$ in plant and hence shows $\mathrm{Zn}$ deficient. Due to the cool and wet weather the availability of $\mathrm{Zn}$ reduced and plant shows deficiency. 


\section{Statistical analysis}

Statistical data was analyzed and evaluated as recommended by Steel, Torei, (1980), all the result recorded on different parameters of plant growth and yield. Means was evaluated using LSD test.

\section{Results and discussion}

Number of tillers plant ${ }^{-1}$

Potassium (K) and zinc ( $\mathrm{Zn})$ significantly affected number of tillers plant ${ }^{-1}$ (Table 1 ). However, interaction between potassium and zinc was non-significant for number of tillers plant $^{-1}$. Mean values for potassium showed that numbers of tillers plant ${ }^{-1}$ were increased with increase in potassium rate and maximum number of tillers plant ${ }^{-1}$ (3.0) were obtained with $150 \mathrm{~kg} \mathrm{~K} \mathrm{ha}{ }^{-1}$. However, it was similar statistically to that of $120 \mathrm{~kg} \mathrm{~K} \mathrm{ha}^{-1}$ (2.9). The minimum tillers plant $^{-1}$ (2.2) were recorded in $\mathrm{K}$ control plots, similar to $90 \mathrm{~kg} \mathrm{~K} \mathrm{ha}^{-1}$ (2.3). In case of zinc, the maximum number of tillers plant $^{-1}$ (2.9) were examined with $10 \mathrm{~kg} \mathrm{Zn}$ $\mathrm{ha}^{-1}$, however statistically similar with $5 \mathrm{~kg}$ $\mathrm{Zn} \mathrm{ha}^{-1}$ (2.7). Zinc control plots (0 kg Zn ha ${ }^{-}$ $\left.{ }^{1}\right)$ produced fewer number of tillers plant ${ }^{-1}$ (2.3). Results are similar to the research of [10] who determined that tillers plant ${ }^{-1}$ were higher when balanced nutrition to the potato crop were given. Potassium applied to crop enhances root growth and increase number of tillers plant ${ }^{-1}$. However when plants were applied with zinc the maximum number of tillers plant ${ }^{-1}$ were noted with 10 $\mathrm{kg} \mathrm{Zn} \mathrm{ha-1,} \mathrm{which} \mathrm{was} \mathrm{similar} \mathrm{to} 5 \mathrm{~kg} \mathrm{Zn} \mathrm{ha-}$ 1. Zinc control plots produced fewer number of tillers plant ${ }^{-1}$. [11] Supported our findings by reporting increase in number of tillers plant ${ }^{-1}$ with increase in zinc level. [12] Also determined that $\mathrm{K}$ improve the plant health vigorous, showed resistance to diseases and also promote leaf number and aerial stems. It is obvious observed that potassium increase number of stems which directly enhance the leaf number further the number of leaves will more when plant height is increasing.

\section{Number of leaves plant ${ }^{-1}$}

Leaves plant $^{-1}$ were considerably affected by potassium $(\mathrm{K})$ and zinc $(\mathrm{Zn})$ (Table 1$)$, while their interaction $(\mathrm{K} \times \mathrm{Zn})$ were nonsignificant (Table1). Plots treated with 150 $\mathrm{kg} \mathrm{K} \mathrm{ha}{ }^{-1}$ produced maximum leaves plant $^{-1}$ (15.7), which was similar to 120 $\mathrm{kg} \mathrm{K} \mathrm{ha}^{-1}$ (15.6). Minimum leaves plant ${ }^{-1}$ (14.1) were observed in potassium control plots. In case of zinc application, maximum leaves plant ${ }^{-1}$ (15.5) and (15.3) were recorded with 10 and $5 \mathrm{~kg} \mathrm{Zn} \mathrm{ha}{ }^{-1}$, respectively. However, minimum leaves plant $^{-1}$ (14.2) were obtained in zinc check plots. [12] Also determined that $\mathrm{K}$ improve the plant health vigorous, showed resistance to diseases and also promote leaf number. It is obvious observed that increasing number of stems directly enhance the leaf number further the number of leaves will more when plant is tallest. Researchers revealed that $\mathrm{K}$ plays an essential part during photosynthesis [13] that facilitate the maximum energy level thus facilitate more number of leaves, maintaining stomatal conductance (opening and closing) on leaf, absorption of water, nutrients translocation, organic acid and vitamin contents concentration in plants. In case of zinc application, higher leaves plant ${ }^{-1}$ were recorded with 10 and $5 \mathrm{~kg} \mathrm{Zn} \mathrm{ha}{ }^{-1}$. However, least number of leaves plant ${ }^{-1}$ were obtained in zinc check plots. [14] Reported increase in number of leaves plant $^{-1}$ with increase in zinc concentration via foliar application. Zinc helps in the formation of auxin such as indole acetic acid. Plants with low Zinc concentration inhibits low levels of indole acetic acid. Zinc synthesized Typtophan which is require for IAA formation. In the absence of this plant hormone plant growth will be stunted mostly internode growth and leaf size and number of leaves will decreased.

\section{Plant height (cm)}

Statistical analysis of the data showed that potassium $(\mathrm{K})$ and zinc $(\mathrm{Zn})$ had significantly affected plant height (Table 1). While interaction between potassium and zinc ( $\mathrm{K} \times \mathrm{Zn})$ was non-significant for plant height. Plots received potassium @ $150 \mathrm{~kg} \mathrm{ha}^{-1}$, produced the taller plants 
$(28.0 \mathrm{~cm})$, similar to $120 \mathrm{~kg} \mathrm{~K} \mathrm{ha}^{-1}(27.4$ $\mathrm{cm})$. The most dwarf plants $(24.3 \mathrm{~cm})$ were examined in potassium check plots. Similarly raise in zinc level increased plant tallness. Maximum plant stature $(27.6 \mathrm{~cm})$ was recorded when zinc was fed@10 kg ha ${ }^{-1}$. However, it was somewhat similar that of $5 \mathrm{~kg} \mathrm{Zn} \mathrm{ha}{ }^{-1}$ $(27.1 \mathrm{~cm})$. Zinc check plots $\left(0 \mathrm{~kg} \mathrm{Zn} \mathrm{ha}{ }^{-}\right.$ $\left.{ }^{1}\right)$ produced dwarf plants $(24.9 \mathrm{~cm})$. Potassium increase Nitrogen use efficiency hence potassium contributed to plant height due to increasing Nitrogen availability and uptake. These findings are supported by the work of [15], who investigate that with the treatment of potassium fertilizer, the taller potato plants were observed. There is increase in plant height, chlorophyll concentration, leaf area, $\mathrm{K}$ concentration, specific gravity, and carbohydrate content when potassium sulfate amount is increased [16]. Similarly increase in zinc level increased plant height. Highest plant was recorded from the plot which receive Zinc @ $10 \mathrm{~kg} \mathrm{ha}^{-1}$. However, it was similar to that of $5 \mathrm{~kg} \mathrm{Zn}$ $\mathrm{ha}^{-1}$. Zinc check plots gave dwarf plants. [17] Stated that zinc is needed for a plant's enzyme formation and associated with hormone (indole acetic acid) formation and deficiency of zinc has been found to reduce leaf size and shortened internodes and hence, limit plant growth.

\section{Number of tubers plant ${ }^{-1}$}

Potassium (K) and zinc ( $\mathrm{Zn})$ had significantly affected number of tubers plant $^{-1}$ (Table 1). However, there interaction was non-significant for number of tubers plant ${ }^{-1}$. Mean values for potassium showed that number of tubers plant ${ }^{-1}$ were increased with increase in potassium rate and maximum number of tubers plant ${ }^{-1}$ (11.9) were obtained with $150 \mathrm{~kg} \mathrm{~K} \mathrm{ha}{ }^{-1}$. However, it was similar to that of $120 \mathrm{~kg} \mathrm{~K}$ $\mathrm{ha}^{-1}$ (11.2). Lowest tubers plant ${ }^{-1}$ (9.3) were noticed in $\mathrm{K}$ check plots, which is similar to $90 \mathrm{~kg} \mathrm{~K} \mathrm{ha}{ }^{-1}$ (9.9). In case of zinc, maximum number of tubers plant ${ }^{-1}(11.3)$ were recorded with $10 \mathrm{~kg} \mathrm{Zn} \mathrm{ha}^{-1}$, which is similar to $5 \mathrm{~kg} \mathrm{Zn} \mathrm{ha}^{-1}$ (10.8). Zinc control plots $\left(0 \mathrm{~kg} \mathrm{Zn} \mathrm{ha}^{-1}\right)$ produced fewer number of tubers plant $^{-1}$ (9.7). The results corroborate with the research of [18] who informed that increase in zinc level increased number of tubers plant ${ }^{-1}$.For crop yield and most favorable size of fruit Zinc is a necessary element, also $\mathrm{Zn}$ is needed in the carbonic enzyme which are present in every photosynthetic tissue and which is required for chlorophyll biosynthesis [9]. Better induction of tubers by $\mathrm{K}_{2} \mathrm{O}$ may be credited to short termed using of soil $\mathrm{pH}$ there by increasing beneficial elements like Nitrogen and potassium which facilitate in more number of tubers per plant. [19] Studied to find out the best potassium dose for potato maximum yield, nutrients use efficiency and quality potatoes under irrigated soil condition on sandy loam soil. Potassium application resulted the best tuber yield by increasing the large and medium grade tubers thus the number of tubers plant ${ }^{1}$ was increased.

\section{Tuber weight plant $^{-1}$ (g)}

Tuber weight plant $^{-1}$ significantly affected by potassium $(\mathrm{K})$ and zinc $(\mathrm{Zn})$ (Table 1$)$, while their interaction ( $\mathrm{K} \times \mathrm{Zn})$ were nonsignificant. Plots treated with potassium $150 \mathrm{~kg} \mathrm{~K} \mathrm{ha}^{-1}$ produced maximum tuber weight plant $^{-1}$ (524 g), which is similar with $120 \mathrm{~kg} \mathrm{~K} \mathrm{ha}^{-1}(512 \mathrm{~g})$. Lowest tuber weight plant $^{-1}(431 \mathrm{~g})$ was observed in potassium control plots $\left(0 \mathrm{~kg} \mathrm{~K} \mathrm{ha}^{-1}\right)$. In case of zinc application, maximum tuber weight plant ${ }^{-1}(503 \mathrm{~g})$ and was noted with $10 \mathrm{~kg} \mathrm{Zn} \mathrm{ha}^{-1}$ which is similar to that of 5 $\mathrm{kg} \mathrm{Zn} \mathrm{ha-1} \mathrm{(490} \mathrm{g),} \mathrm{respectively.}$ However, minimum tuber weight plant $^{-1}$ (452 g) was obtained in zinc control plots

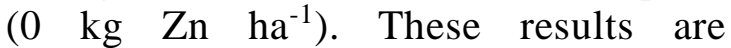
somewhat similar with the research of [20] who examined that maximizing the tuber weight per plant directly increase the yield as potassium effect both value and amount of tubers indirectly synergistic interaction with rest of the nutrients (particularly with Nitrogen) and agronomic practices. [21] Reported that the weight and size of tubers were increased with the treatment of $\mathrm{K}$ which 
in turn increased the amount of large sized profitable tubers. In case of zinc application, maximum tuber weight plant $^{-1}$ was recorded with 10 and $5 \mathrm{~kg} \mathrm{Zn}$ $\mathrm{ha}^{-1}$. However, minimum tuber weight plant $^{-1}$ was obtained in zinc control plots. The results showed similarities with the research of [22] who examined that increasing in zinc level improved tuber weight plant $^{-1}$. $\mathrm{Zn}$ has particular physiological functions and also has a positive effect on crops production so crops qualitative and quantitative production strongly depends on Zinc in the soil.

Table 1. Number of tillers plant ${ }^{-1}$, Number of leaves plant ${ }^{-1}$, Plant height $(\mathrm{cm})$, Number of tubers plant ${ }^{-1}$ and Tuber weight plant $^{-1}(\mathrm{~g})$ of potato as affected by potassium and zinc application

\begin{tabular}{|c|c|c|c|c|c|}
\hline $\begin{array}{c}\text { Potassium Levels } \\
\left(\mathrm{kg} \mathrm{ha}^{-1}\right)\end{array}$ & $\begin{array}{l}\text { Number of } \\
\text { tillers plant }^{-1}\end{array}$ & $\begin{array}{c}\text { Number of } \\
\text { leaves plant }{ }^{-1}\end{array}$ & $\begin{array}{c}\text { Plant height } \\
\text { (cm) }\end{array}$ & $\begin{array}{c}\text { Number of } \\
\text { tubers plant }^{-1}\end{array}$ & $\begin{array}{c}\text { Tuber weight } \\
\text { plant }^{-1}(\mathrm{~g})\end{array}$ \\
\hline 0 & $2.2 \mathrm{~b}$ & $14.1 \mathrm{c}$ & $24.3 \mathrm{c}$ & $9.3 \mathrm{~b}$ & $431 \mathrm{c}$ \\
\hline 90 & $2.3 \mathrm{~b}$ & $14.6 \mathrm{bc}$ & $26.3 \mathrm{~b}$ & $9.9 \mathrm{~b}$ & $459 \mathrm{~b}$ \\
\hline 120 & $2.9 \mathrm{a}$ & $15.6 \mathrm{ab}$ & $27.4 \mathrm{ab}$ & $11.2 \mathrm{a}$ & $512 a$ \\
\hline 150 & $3.0 \mathrm{a}$ & $15.7 \mathrm{a}$ & $28.0 \mathrm{a}$ & $11.9 \mathrm{a}$ & $524 a$ \\
\hline LSD $(\mathrm{P} \leq 0.05)$ & 0.54 & 1.08 & 1.22 & 1.00 & 19.36 \\
\hline \multicolumn{6}{|c|}{ Zinc Levels $\left(\mathrm{kg} \mathrm{ha}^{-1}\right)$} \\
\hline 0 & $2.3 \mathrm{~b}$ & $14.2 \mathrm{~b}$ & $24.9 \mathrm{~b}$ & $9.7 \mathrm{~b}$ & $452 b$ \\
\hline 05 & $2.7 \mathrm{ab}$ & $15.3 \mathrm{a}$ & $27.1 \mathrm{a}$ & $10.8 \mathrm{a}$ & $490 \mathrm{a}$ \\
\hline 10 & $2.9 \mathrm{a}$ & $15.5 \mathrm{a}$ & $27.6 \mathrm{a}$ & $11.3 \mathrm{a}$ & $503 a$ \\
\hline LSD $(\mathrm{P} \leq 0.05)$ & 0.46 & 0.94 & 1.06 & 0.86 & 16.76 \\
\hline Interaction (K x Zn) & ns & ns & ns & ns & ns \\
\hline
\end{tabular}

\section{Conclusions}

It can be concluded from the research work that increase in potassium rate up to $120 \mathrm{~kg}$ $\mathrm{ha}^{-1}$, could improve potato quality, growth, and yield. Zinc used @ of $10 \mathrm{~kg} \mathrm{ha}^{-1}$, showed better performance in term of growth, quality and yield of potato. However, it wasn't significantly different from $5 \mathrm{~kg} \mathrm{Zn} \mathrm{ha}{ }^{-1}$. The interactive effect of potassium and zinc on growth, yield and quality of potato was not significant. According to the result it is recommended that application of zinc @ $5 \mathrm{~kg} \mathrm{ha}^{-1}$ and potassium@120 kg ha ${ }^{-1}$ improve potato growth, productivity and quality significantly. Further research is required on potassium and zinc application in Khyber Pakhtunkhwa for superior crops productivity and profitability under different cropping pattern.

\section{Authors' contributions}

Conceived and designed the experiments: MW Khan \& A Rab, Performed the experiments: MW Khan, Analyzed the data: R Ali \& M Sajid, Contributed materials/ analysis/ tools: MN Khan, A Ali,
MA Khan, W Pervez \& F Amin, Wrote the paper: MW Khan.

\section{References}

1. Spooner DM \& Bamberg JB (1994). Potato genetic resources of resistance and systematics. Amer Potato J 71: 325-338.

2. MINFA (2010-2011). Govt. of Pakistan Ministry of Food, Agriculture and Livestock, Economic Wing Islamabad. Agric Experiment Station Bulletin 90:46.

3. Bansal SK \& Trehan SP (2011). Effect of potassium on yield and processing quality attributes of potato. Karnataka J Agric Sci 24 (1): 48-54.

4. Mousavi SR, Galavi M \& Rezaei M (2013). Zinc (Zn) importance for crop production A Review. Intl J Agron Plant Prod 4(1): 64-68.

5. Kalavati Prajapatil \& Modi HA (2012). The importance of potassium in plant growth a review. Indian $J$ of Plant Sci 1(02-03). ISSN: 2319-3824.

6. Gupta VK, BP Sing Karwasa \& Raj H (1988). Zinc in India agriculture, dept. of soil. Haryana Agri University Hisar. 
7. Millikan CR (1953). Relative effect of $\mathrm{Zn}$ and $\mathrm{Cu}$ deficiencies in Lucerne and subterranean clover. Abst J Biol Sci 6: 164-177.

8. Yosefi K, Galavi M, Ramrodi M \& Mousavi SR (2011). Effect of biophosphate and chemical phosphorus fertilizer accompanied with micronutrient foliar application on growth, yield and yield components of maize (Single Cross 704). Aust J Crop Sci 5(2): 175-180.

9. Ali S, Riaz KA, Mairaj G, Arif M, Fida M \& Bibi S (2008). Assessment of different crop nutrient management practices for yield improvement. Aust $J$ Crop Sci 2(3): 150-157.

10. Ayyub, CM, Hanjra MA, Saeed T, Malik AU \& Abbassi NA (1998). Natural farming, profitability and sustainable development in vegetable production-II. Pak J Sci Res 50(3-4): 17.

11. Panomwan B, Ismail C, Benjavan R \& Chanakan P (2013). Effect of different foliar zinc application at different growth stages on seed zinc concentration and its impact on seedling vigor in rice. Soil Science and Plant Nutrition pp 180-188

12. Marschner H (1995). Mineral nutrition of higher plants. $2^{\text {nd }}$ Edition. Academic Press, London. 436-460.

13. Erland L, Asa L, Lars W, Dharani DB, Erik A \& Erik A (2016). Potassium phosphite combined with reduced doses of fungicides provides efficient protection against potato late blight in large-scale field trials. Crop Protection pp 42-55.

14. Zaynab D, Abbas H \& Mir HR (2011). Effect of Zinc Application on Growth and Some Biochemical Characteristics of Costmary (Chrysanthemum balsamita L.). J of Communications in Soil Sci and Plant Analysis 2: 24932503.
15. Pravin Singh (2017). Effect of potassium and zinc on growth, yield and quality on sweet potato (Ipomoea batatas L) cv. CO-34. Published on 2017-05-15. ISBN-13: 978-3-33008982-2

16. Al Moshileh, AM \& Errebi MA (2004). Effect of various potassium sulfate rates on growth, yield and quality of potato grown under sandy soil and arid conditions. IPI regional workshop on Potassium and Fertigation development in West Asia and North Africa; Rabat, Morocco 2428.

17. Acquaah \& George (2002). Horticulture: principles and practices. 2nd ed. Upper Saddle River, New Jersey: Prentice Hall.

18. Abd El Baky MMH, Ahmed AA, ElNemr MA \& Zaki MF (2010). Effect of potassium fertilizer and foliar zinc application on yield and quality of sweet Potato. Biol Sci 6(4): 386-394.

19. Singh SK \& Lal SS (2012). Effect of potassium nutrition on potato yield, quality and nutrient use efficiency under varied levels of nitrogen application. Potato J 39 (2): 155-165.

20. Sharma SK \& Singh SP (2017). Effect of potassium, zinc and farm yard manure on growth, yield, nutrient uptake and quality of potato (Solanum tuberosum L). Inter $J$ of Chemical Studies 5(5): 818-822.

21. Martin P \& JI (1989). Physiological processes related to handling and storage quality of crops. In: Proceedings of the 21st IPI Colloquium on: methods of $\mathrm{K}$ research in plants, held at Louvain la Neuve, Belgium. International Potash Institute, Bern, Switzerland 219-248.

22. Gandomkar A (2016). Effects of phosphorus-zinc interactions on the yield of potato cultivars. Specialty $J$ of Agri Sci 2(2): 98-101. 